This item was submitted to Loughborough's Research Repository by the author.

Items in Figshare are protected by copyright, with all rights reserved, unless otherwise indicated.

\title{
Interfirm collaboration as a performance-enhancing survival strategy within the business models of ethnic minority-owned urban restaurants affected by COVID-19
}

\section{PLEASE CITE THE PUBLISHED VERSION}

https://doi.org/10.1108/IJEBR-04-2021-0279

\section{PUBLISHER}

Emerald

\section{VERSION}

AM (Accepted Manuscript)

\section{PUBLISHER STATEMENT}

This paper was accepted for publication in the journal International Journal of Entrepreneurial Behaviour and Research and the definitive published version is available at https://doi.org/10.1108/IJEBR-04-2021-0279

\section{LICENCE}

CC BY-NC 4.0

\section{REPOSITORY RECORD}

Crick, Jim, Dave Crick, and Shiv Chaudhry. 2021. "Interfirm Collaboration as a Performance-enhancing Survival Strategy Within the Business Models of Ethnic Minority-owned Urban Restaurants Affected by COVID-19". Loughborough University. https://hdl.handle.net/2134/14748663.v1. 


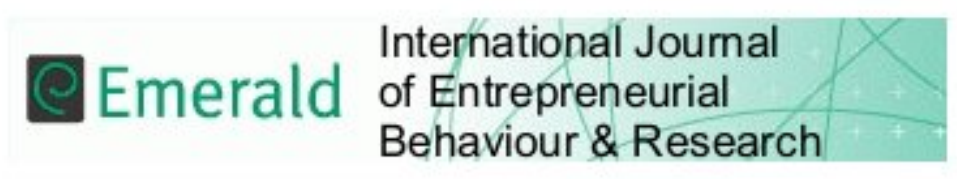

\section{Inter-firm Collaboration as a Performance-Enhancing Survival Strategy within the Business Models of Ethnic Minority-Owned Urban Restaurants Affected by COVID-19}

\begin{tabular}{|r|l|}
\hline Journal: & International Journal of Entrepreneurial Behavior \& Research \\
\hline Manuscript ID & IJEBR-04-2021-0279.R1 \\
\hline Manuscript Type: & Research Paper \\
\hline Keywords: & Resource-based theory, Ethnic Groups \\
\hline \multicolumn{2}{|l}{} \\
\end{tabular}

\section{SCHOLARONE" Manuscripts}




\title{
Inter-firm Collaboration as a Performance-Enhancing Survival Strategy within the Business Models of Ethnic Minority-Owned Urban Restaurants Affected by COVID-19
}

\begin{abstract}
Purpose: Guided by resource-based theory, this investigation examines the extent to which knowledge sharing as part of inter-firm collaboration serves as a performance-enhancing strategy; that is, in the context of assisting ethnic minority-owned urban restaurants to survive during a major market disruption. Specifically, the study features owner-managers perceptions concerning the evolving environmental circumstances associated with the novel coronavirus (COVID-19) pandemic.
\end{abstract}

Design/methodology/approach: Data collection took place among owner-managers of urban restaurants in a Canadian city during the COVID-19 pandemic in late 2020. This featured semi-structured interviews with restaurants' owner-managers originating from various ethnic origins together with secondary data where possible. Data analysis followed an adapted Gioia approach.

Findings: Examples of inter-firm collaboration include restaurants' owner-managers leveraging social capital and sharing knowledge about the effects of legislation and health guidelines on operating procedures, together with good and bad practices where firms have pivoted their business models via take-outs, patio dining and in-room dining. Irrespective of the strength of network ties (within and across ethnic communities), owner-managers were motivated to share information to facilitate their survival. Nevertheless, this study raises questions over the extent that certain decision-makers exhibit strategic flexibility responding to environmental conditions together with their respective ability to engage/retain customers plus service-oriented employees. Additionally, whether some ownermanagers will continue to collaborate with their competitors after COVID-19 ends, and if so, with whom and the magnitude of activities. In particular, 'trust' via psychological contracts and 'complementary strategies' among partners across co-ethnic and different ethnic origins are key considerations.

Originality: A body of knowledge exists addressing the notions of both inter-firm collaboration and market disruptions in the broader cross-disciplinary literature. However, the inter-firm collaborative practices of small firms with ethnic minority ownership that are otherwise rivals remain under-researched. More specifically, inter-firm collaboration as a survival strategy for owner-managers during the market disruption arising from a crisis situation features as an original contribution.

Keywords: COVID-19; Ethnicity, Inter-firm Collaboration; Strategic Flexibility.

\section{Introduction}

"Evidence, however, is lacking on how small operators, who are likewise competitive, can establish cooperation and collaboration." (Rivera, 2019, p. A1).

Underpinned by resource-based theory (Barney, 1991; 2018), the objective of this cross-disciplinary study is to examine how decision-makers in restaurants owned by members of ethnic minority communities can utilize 
knowledge sharing as a specific aspect of inter-firm collaboration to help survive and enhance performance during the evolving environmental circumstances associated with the novel coronavirus (COVID-19) pandemic. By way of background, various patterns of migration and integration into certain countries have occurred over generations, leading to the contemporary multi-cultural marketplace (Demangeot and Sankaran, 2012). Additionally, degrees of mixed embeddedness has taken place across ethnic communities (countries of origin and settlement as per Kloosterman, 2010; Jones et al., 2014). In fact, these practices have manifested in various businesses in the hospitality sector (among others) being owned by members of various ethnic minority communities (Ram et al., 2000a; 2000b; 2002; Chaudhry and Crick, 2004; Josiam and Monteiro, 2004; Abdullah et al., 2009; Jang et al., 2011). Nevertheless, despite businesses more generally failing for a number of reasons (Parsa et al., 2005), a body of research suggests that various issues influence the likelihood of ethnic minority-owned firms' survival and resilience to environmental conditions, including access to capital, levels of education and limited assets (Bruder et al., 2011 Bewaji et al., 2016; Crick et al., 2016). However, the survival practices of ethnic minority-owned firms at a time of severe market disruption/crisis remains relatively under-researched, making this current investigation both important and timely.

For clarity, two key concepts are considered, namely, 'coopetition' (as a term widely associated with inter-firm collaboration) and 'market disruptions'. First, various terms exist to describe and operationalize collaboration among supply chain partners; also, with competitors, such as alliances, inter-firm rivalry and coopetition (Pangarkar, 2007; Bouncken et al., 2015; 2020; Cui et al., 2018; Crick and Crick, 2019; Papaioannou et al., 2020). Coopetition involves "a paradoxical relationship between two or more actors, regardless of whether they are involved in horizontal or vertical relationships, simultaneously involved in cooperative and competitive interactions" (Bengtsson and Kock, 2014, p. 180). This current study focuses on horizontal as opposed to vertical relationships among restaurants owned by members of ethnic minority communities. It therefore builds on a body of literature that has existed for some time involving the notion of symbiotic entrepreneurship that can occur across both domestic and international 
networks (Etemad et al., 2001; Wright and Dana, 2003; Dana et al., 2008), whereby independent firms cooperate voluntarily for performance-enhancing reasons like increased efficiency and profit.

Second, existing literature highlights that the notion of a market disruption is somewhat broad, taking various forms other than the COVID-19 pandemic featuring in this current investigation. Diverse examples include disruptive business models such as via the 'internet of things' (Guttentag and Smith, 2017); natural disasters (Morrish and Jones, 2020); financial crises (Pizam, 2009; Johnstone et al., 2020); product-harm crises (Gao et al., 2015); as well as epidemics and pandemics (Tse et al., 2006; Chuo, 2014; Baum and Hai, 2020; Jiang and Wen, 2020; Sigala, 2020). Nevertheless, an underlying similarity in earlier studies that address market disruptions together with the term 'crisis management', is the need for decision-makers to develop capabilities and build resilience within their respective business models (Stafford et al., 2002; Israeli, 2007; Seo and Jang, 2013).

Consequently, it is necessary to link the underlying two core concepts together in order to contribute to knowledge in this current study's cross-disciplinary domain. Indeed, despite from a marketing perspective Bengtsson and Kock (2014) viewing coopetition as 'paradoxical', from a broader entrepreneurship lens, such activities appear seemingly 'rational' for under-resourced firms, especially at times of crisis like a major market disruption. For example, Crick and Crick (2020) utilized secondary data to illustrate examples across various trade sectors during the COVID-19 pandemic of under-resourced rivals collaborating rather than employing an individualistic business model as a performance-enhancing strategy. The impact of inter-firm collaboration on a firm's business model is a key consideration, since Baden-Fuller and Haefliger (2013, p. 419) define this as "a system that solves the problem of identifying who is (or are) the customer(s), engaging with their needs, delivering satisfaction, and monetizing the value". It follows that decision-makers need to evolve their business models to enhance performance and indeed minimize the potential for failure reflecting changing circumstances (as per Osterwalder and Pigneur, 2010; Gassmann et al., 2014), such as the market disruption caused by COVID-19. Nevertheless, although certain firms 
are adapting their business models (Crick and Crick, 2020; Lund Pedersen and Ritter, 2020), Sheth (2020) questions whether old customer habits will die or return.

Such a consideration raises uncertainty for owner-managers' decision-making during the evolving circumstances resulting from COVID-19 and the need for 'readiness' to improvise/adapt strategies (Hughes et al., 2020). Not least, since enhancing customers' experiences to facilitate organizational reputation and build loyalty is important (Foroudi et al., 2016); yet, achieving such outcomes may be problematic in times of a crisis. In addressing the previously mentioned objective, two contributions arise from this current study:

1. Unique insights during the COVID-19 pandemic feature information sharing among owner-managers of businesses with different ethnic ownership as a facet of inter-firm collaboration activities at a time of crisis. This provides under-resourced decision-makers with knowledge as a mutually beneficial asset to help performance related outcomes, especially survival, during a crisis (building on resource-based theory as per Barney, 1991; 2018). Illustrations highlight the importance of developing social capital (irrespective of the ethnic ownership of particular businesses); not least, via trust and engaging in inter-firm collaboration activities with complementary partners to minimize tensions, especially among those in close proximity (building on Dana et al., 2013; Felzensztein et al., 2014; Geldes et al., 2015). Nevertheless, the strength of co-ethnic and inter-community network ties varied among rivals, especially depending on the extent to which direct as opposed to indirect competition existed. Such considerations lead to speculative questions over the likelihood of inter-firm collaboration continuing after the pandemic ends or at least the magnitude of the activities among certain firms.

2. Further insights involve the notion of 'strategic flexibility' in respect of decision-makers' business models responding to shared knowledge regarding changing conditions during COVID-19; also, associated learning and readiness to move forward during and after the crisis (building on Priem and Butler, 2001; Hughes et al., 2020). In particular, for family-owned businesses that are prevalent in certain sectors, the need exists to utilize social capital 
(see Arregle et al., 2007; Herrero and Hughes, 2019) and not restrict decision-making among family members. In fact, irrespective of the resources/capabilities possessed, the need exists for owner-managers to have the ability to rapidly pivot their evolving business models (as per Osterwalder and Pigneur, 2010; Gassmann et al., 2014).

This study continues first, via consideration of contextual issues in respect of crises with a focus on the COVID-19 pandemic, before second, a theoretical underpinning follows regarding the framing literature. Third, an evaluation of the methodological approach employed takes place, before fourth, consideration of the findings follows. Fifth, a discussion of those findings offers unique insights in respect of their contribution to the existing cross-disciplinary literature. Sixth, conclusions, implications and areas for further research end the paper.

\section{Context}

Since the beginning of 2020, the global impact of the novel coronavirus (COVID-19) pandemic has been apparent in various respects, especially with a large number of cases and deaths (Worldometer, 2021). To date, evolving regulations, varying practices among firms, and contrasting customer behavior have been evident (Baum et al., 2020; Chen, 2020; Knight et al., 2020; Yang et al., 2020). For example, to varying degrees, governments around the world have ordered lockdowns, many employees are working from home, consumers have been panic buying certain items, and large-scale travel and trading restrictions have been enforced (BBC News, 2020; Fox News, 2020; CNN, 2020; United Kingdom Government, 2020). In fact, certain countries or major urban areas within them have become hotspots for COVID-19 (Telegraph, 2020; Washington Post, 2020). The impact of this market disruption for businesses has been dramatic with some trade sectors performing better than others (MSN.com, 2020a), although trading rules have varied across countries. In response, certain firms' owner-managers across sectors have pivoted their business models in particular ways (Fortune, 2020; MSN.com, 2020a; Pantano et al., 2020; Ritter and Lund Pederson, 2020), such as changing production to items in demand like personal protective equipment. In short, given customers' perceptions of risks in a climate of changing legislation (Foroudi et al., 2021), 
although certain firms have struggled to survive, others have exhibited varying degrees of resilience (Alonso et al., 2020; Brizek et al., 2021; Song et al., 2021); not least, by adapting operating procedures (Breier et al., 2021).

A key consideration for firms' owner-managers across a variety of sectors during the pandemic crisis is whether to continue internalizing decision-making by operating under an individualistic as opposed to a collaborative business model (Crick and Crick, 2020). Specifically, whether to build social capital (Visentin et al., 2021); for example, engage in forms of inter-firm collaboration like sharing resources and capabilities (as per Financial Times, 2020; Independent, 2020; New York Times, 2020; Security, 2020; The Guardian, 2020; Wyllie, 2020). These primarily practitioner-oriented examples occur across sectors such as charities, healthcare, through to cyber-security; the over-riding consistency being firms that previously operated via an individualistic business model have collaborated with other firms for mutually beneficial outcomes.

Turning to restaurants (consistent with many other businesses), these have been subject to emergency legislation forcing them to close their doors to the public like for dine-in services during certain periods; the effect being that business failure rates across various sectors including restaurants are widely reported (CNN, 2020; MSN.com, 2020b). Like a number of under-resourced businesses with low or unstable cash-flows across a variety of sectors (see Eggers, 2020), restaurants are vulnerable during crises despite certain government policy makers offering benefits/services (for example, Canada.ca, 2020). Indeed, in terms of the country context of this current investigation, about 800,000 Canadian restaurant jobs were lost in March 2020 (globalnews.ca, 2020a) and like employers across many sectors, a need exists to support their workforce (see Carnvale and Hatak, 2020). Guides of best practices are nonetheless available to owner-managers as issues associated with COVID-19 evolve (Restaurants Canada, 2020). However, across the world, the stark reality is that certain restaurants will potentially not re-open (MSN, 2020b). In short, for a number of sectors including restaurants, the future is uncertain and as Schwartzel et al. (2020) note: "the new normal will look anything but." 


\section{Literature Review}

\section{Ethnic Minority-Owned Businesses}

Following the prior contextual considerations associated with the disruption caused by COVID-19, in this current study that investigates the practices of restaurants owned by members of ethnic minority communities, a prima facie notion is that such firms may operate somewhat differently to those in the wider sector. Indeed, Smallbone et al. (2005: 43) note that "most of the existing literature on ethnic minority-owned firms is based, either explicitly or implicitly, on the view that businesses with ethnic minority owners are 'different' from the rest of the population, both in terms of their behavioural characteristics and in terms of the types of problems that they face". Moreover, as the Introduction section alluded to, migration has occurred for some time (Light, 1972; Dana, 2007) leading to varying degrees of mixed embeddedness in particular countries (as per Kloosterman, 2010; Jones et al., 2014). The formation of 'enclaves' containing relatively high numbers of co-ethnic communities in some localized areas has occurred following migration and as members of ethnic communities move to later generations (Wilson and Portes, 1980; Werbner, 2001). Nevertheless, regarding business practices, depending on owner-managers' growth aspirations, a potential need to 'break-out' of niche markets has also been noted (Ram and Hillin, 1994; Basu, 2010).

Earlier studies often focus on relatively stable environmental conditions in contrast to the crisis context of the COVID-19 pandemic in this current study, whereby owner-managers' objectives and associated strategies may pivot to maintaining business survival in response to the market disruption. Under 'normal' environmental operating conditions that reflect more stability compared to the context of COVID-19, certain issues are important considerations in this current investigation. First, Werbner (1994) notes that 'social networks' are a potential key resource; in particular, the associated performance-enhancing knowledge regarding cultural issues and the relatively low operating costs by employing family and co-ethnic employees (Jones et al., 1993; Chaudhry and Crick, 2004). Nevertheless, it is stressed that the broader notion of 'family ownership' was not the explicit focus 
under investigation, despite the recognition that governance and support mechanisms can influence decisionmaking (Felzensztein and Gimmon, 2021). Importantly, this study appreciated that various family-owned businesses operate in the restaurant sector including those with owner-managers from ethnic-minority backgrounds (Chaudhry and Crick, 2004; Crick et al., 2016). More broadly, recognition also existed that family-owned firms typically represent a high proportion of employment across various countries (Canziani et al., 2020).

Such issues were relevant to this current study because family-owned firms (irrespective of ethnic ownership) may exhibit certain resources/capabilities including their organizational culture, reputation, human capital and networks (Habbershon and Williams, 1999; Sirmon and Hitt, 2003; Huybrechts et al., 2011; Zellweger et al., 2012; Beck and Prügl, 2018; Herrero and Hughes, 2019; Estrada-Robles et al., 2020). Moreover, Reay et al. (2015) noted coexisting institutional logics, highlighting the importance of decision-making benefiting the family, business and community. Although exceptions exist, firm ownership has nonetheless often been implicit as opposed to explicit in certain prior studies regarding inter-firm collaboration (see Niemelä, 2004; Roessl, 2005). Consequently, returning to the ethnic minority focus of this current investigation, such considerations are pertinent since they may affect the extent to which co-ethnic ties form part of inter-firm collaborative relationships at a time of a crisis and indeed, influence co-ethnic employment based on social networks, especially among family businesses.

Second, earlier studies provide evidence to suggest that despite potential motives for starting businesses (such as cultural knowledge), sometimes problems exist among owner-managers from ethnic-minority backgrounds. These issues include experience with racism, an inability to raise appropriate capital; also, support ${ }^{1}$ to help overcome adverse cultural and institutional conditions (Min, 1987; Jones et al., 1992; Ram and Smallbone, 2003; Bruder et al., 2011; Aliaga-Isla and Rialp, 2013; Carter et al., 2015). In fact, Chreim et al. (2018) highlight a potential 'double

\footnotetext{
${ }^{1}$ A body of knowledge exists on various stakeholders' generic assistance for owner-managers irrespective of ethnicity ranging from start-ups through to established firms' evolving business models like via internationalisation (Crick, 1992; Crick and Crick, 2018). However, recognition also exists that particular stakeholders often need to differentiate their support for ethnic-minority-owned firms such as via a cultural affiliation (Chaudhry and Crick, 1998; Oc and Tiesdell, 1999; Crick and Chaudhry, 2000).
} 
disadvantage' regarding gender and ethnicity; specifically, opportunities are sometimes contained for certain female immigrant entrepreneurs' because of cultural/institutional factors.

\section{Inter-firm Collaboration}

The advantages of engaging in inter-firm collaboration are widely recognized; that is, under-resourced firms obtaining performance-enhancing resources and/or capabilities from rivals as opposed to employing an individualistic business model (Bernal et al., 2002; Ritala, 2012; Czakon and Czernek, 2016; Velu, 2016; Kraus et al., 2019; Czakon et al., 2020; Estrada and Dong, 2020; Crick et al., 2021a). Even so, earlier studies also recognize the importance of effectively managing potential tensions to minimize opportunistic behavior among partners (RazaUllah et al., 2014; Bouncken et al., 2018; Lascaux, 2020; Crick and Crick, 2021a). Not least, because ownermanagers undertake risk/reward considerations when selecting rivals to collaborate with, since not all competitors are the same (Chiambaretto et al., 2020; Yan et al., 2020). In fact, social capital is often important in developing effective network relationships and especially those in close proximity (Felzensztein et al., 2010; 2014; Geldes et al., 2015; Chowdhury et al., 2020; Crick and Crick, 2021b).

However, inter-firm collaboration within the tourism/hospitality context remains relatively under-researched in comparison to other sectors like agriculture, alcohol and high-tech included in the previously mentioned existing literature (for example, Wang and Krakover, 2008; Czakon and Czernek, 2016; Crick et al., 2021b). Illustrations nonetheless arise depending on how broadly the term 'hospitality' is utilized (following earlier research like King, 1995; Rivera, 2020) and the specific business models employed. For example, although eco-systems exist that support firms in various sectors (Ratten, 2020), some business clusters ${ }^{2}$ contain firms engaged in degrees of interfirm collaboration associated with their augmented business models, like among wine producers. Using this

\footnotetext{
2 Business clusters are common in sectors like retail and hospitality/tourism like accommodation through to restaurants (Chaudhry and Crick, 2003; 2004; Crick \& Crick, 2016; Crick et al., 2016; 2018). Not least, regarding restaurants, to reflect ethnic cuisines typified by China Town, Little Italy, Korea Town, etc.
} 
illustration, certain wine producers engage in forms of inter-firm collaboration to facilitate core wine sales domestically and overseas; this includes various practices to sell wine at cellar doors/tasting rooms, alongside operating cafes, restaurants, etc. as part of wine tourism/hospitality activities (Dana et al., 2013; Crick, 2015; Crick and Crick, 2015; Granata et al., 2018; Felzensztein et al., 2019; Crick et al., 2021a).

\section{Inter-firm Collaboration Guided by Resource-Based Theory}

A body of knowledge exists in respect of resource-based theory (as per Barney, 1991; Lavie, 2006; Kellermanns et al., 2016) regarding a relationship between firms' resources/capabilities and their performance. To facilitate a competitive advantage, a firm's utilization of their respective resources and capabilities can result in assets being well organized and of value, rare, inimitable and non-substitutable (Barney, 1991). Nevertheless, simply the possession of particular resources and/or capabilities does not always lead to performance enhancement; instead, strategic flexibility and readiness in decision-making is often necessary (Priem and Butler, 2001; Hughes et al., 2020). Indeed, strategy implementation is a core consideration for owner-managers; not least, at the time of COVID19, whereby they need to prepare their business for a post pandemic world (Lund Pederson and Ritter, 2020).

Recently, Barney (2018) recognized the role of stakeholders in the resources/capabilities-performance relationship, namely, an issue important within this current study involving inter-firm collaboration. For example, owner-managers of under-resourced organizations can collaborate with rivals via the sharing of resources (such as equipment and funds) and/or capabilities (like knowledge and experience) to help lead to mutually beneficial outcomes (see, Bouncken and Kraus, 2013; Gnyawali and Charleton, 2018; Hannah and Eisenhardt, 2018; Hoffmann et al., 2018). In other words, inter-firm collaboration activities can assist partners' performance-enhancing activities in comparison to utilizing their own restricted assets when employing an individualistic business model (Velu, 2016). More specifically, mutual benefits are likely if effective management of trustworthy relationships minimizes potential tensions (Raza-Ullah et al., 2014; Bouncken et al., 2018; Lascaux, 2020; Crick, 2020; Crick and Crick, 2021a). For example, Crick and Crick (2021a) suggest that certain 'psychological contracts' often exist based on trust within 
informal network ties; as opposed to, or in addition to (in the case of formal alliances), contractual arrangements. Luo et al. (2007, p. 81) highlight the potential risks involved when collaborating with competitors. "Cooperation with competitors needs to be carefully considered and judiciously executed because an over-reliance on highly-intensive competitor alliances may be just as harmful as under-using such alliances. Excessive cooperation may lead to freeriding and opportunistic exploitation, a potential loss of proprietary, technological, and marketing capabilities, and a possible dulling of a firm's incentives to stay customer-focused". It therefore follows from a stakeholder perspective of resource-based theory that working with complementary and trustworthy partners (in this case rivals) increases the likelihood of enhancing performance (see Barney, 2018).

Inter-firm Collaboration from an 'Outside-in' Perspective

As previously alluded to, irrespective of a firm's resources and capabilities, market disruption can occur due to environmental circumstances and this leads to consideration of an 'outside-in' perspective (as per Day, 2014; Day, 2020); namely, decision-makers are led by issues associated with the market. To illustrate, Day (2014, p.28) offers examples of questions for decision-makers from an outside-in perspective. "How and why are customers changing? What new needs do they have? What can we do to solve their problems and help them make more money? What new competitors are lurking around the corner, and how can we derail their efforts?" Such issues are important in this current study given that market conditions have changed due to the impact of COVID-19, including legislation affecting the way restaurants can operate and provide value to customers via associated changes in business models (Globalnews.ca, 2020b). Therefore, it follows that instead of attempting to 'derail' competitors (as per Day, 2014), employing a stakeholder perspective of resource-based theory (Barney, 2018) suggests mutual benefits from inter-firm collaboration can arise for owner-managers of certain under-resourced rival firms.

\section{Research Focus}

The previous literature suggests that during a market disruption such as the COVID-19 pandemic at the time of this current study, under-resourced firms owned by members of ethnic minority communities might limit their 
performance by internalizing decision-making and there is potential merit in exploring the opportunity of engaging in inter-firm collaborative activities. In practice however, it is incumbent on decision-makers to enter relationships with trustworthy and complementary rivals to avoid opportunistic behavior; hence, achieve mutually beneficial outcomes. It is therefore worthwhile re-stating the objective of this study, namely, is to examine how decisionmakers in restaurants owned by members of ethnic minority communities can utilize knowledge sharing as a specific aspect of inter-firm collaboration to help survive and enhance performance during the evolving environmental circumstances associated with the novel coronavirus (COVID-19) pandemic. It is nonetheless re-emphasized that this current study focuses solely on information sharing as opposed to broader resources and/or capabilities sharing as the later Findings section indicates this was the only form of inter-firm collaboration undertaken.

\section{Methods \\ Data Collection}

Affecting data collection in this investigation was the evolving legislation in Canada that varied not only across provinces, but also within a province, influenced by varying cases of COVID-19 (see globalnews.ca, 2020b). For example, after various closures of in-house dining, some provinces opened patio dining of restaurants before others; also, particular cities within certain geographically diverse provinces opened on different dates. At the time of writing, in-house dining had re-started within the region under investigation subject to social distancing affecting the number of customers, but then stopped again due to rising cases of COVID-19. Selection of interviewees followed a snowball sampling approach based on contacts with certain owner-managers that led to recommendations of others with whom they had relationships.

Given the evolving context, this study features data collection taking place via semi-structured interviews (observing social distancing) with 40 owner-managers of restaurants selling different cuisines in a single city and surrounding suburbs in late 2020 and this forms the research boundary. Appendix 1 outlines an interview template. The need to include a purposive sample of restaurants with contrasting ethnic ownership was considered important to represent 
a varied population. A recognition exists that many businesses in the restaurant sector across countries are familyowned (Chaudhry and Crick, 2004; Crick et al., 2016, Felzensztein and Gimmon, 2021). However, no claim is made in this current study to suggest all interviewees met widely accepted criteria to justify the term 'family-owned businesses' (see Chua et al., 1999). Interviewees were asked three questions. First, do you consider your organization to be a family business? Second, does a major family own $51 \%$ or more of the equity of your organization? Third, is your business governed and/or managed with the intention to shape and pursue a major family's vision? Owner-managers of various firms had equity divided across families and governance did not shape a major (vis-à-vis their equity) single family's vision. As such, this study does not suggest the criteria of Chua et al. (1999) were met and therefore the focus is to contribute to the ethnicity rather than family-firm literature.

To maintain anonymity, withholding of the name of the city is necessary, as are firm characteristics. For example, if mention of an Italian or Chinese restaurant within a specific city took place, that firm may be difficult to identify. This is due to the relative prevalence of such establishments unless accompanied by further characterizing data in a named area, as more information makes it easier to identify a firm. In contrast, as a further illustration, if mention of a Greek restaurant in an area followed even without any distinguishing characteristics, this would be even easier to identify the firm due to the relatively limited number of establishments selling that ethnic cuisine in particular cities.

Earlier research highlights potential positive and negative issues associated with how scholars address qualitative research and offer guidelines that featured as considerations in the current study (Dana and Dana, 2005; Dana and Dumez, 2015; Crick, 2021). For example, establishing a point of reaching theoretical saturation in studies is difficult, so in this investigation, data collection stopped at a point that major themes repeated. In fact, diseconomies in finding new key data occurred earlier, but more data collection took place to be sure of reaching a point of theoretical saturation. No claims follow in respect of a thick description of data consistent with case study research (see, for example, Stake, 1995); instead, the subsequent Findings section focuses on interviewees' responses across 
participating firms. Triangulation occurred against secondary data where possible like via the Internet, such as industry reports and firms' websites. For example, if interviewees suggested particular practices changed following the start of COVID-19 like moving to a restricted on-line menu, this was easily verifiable against a request to view the hard copy of the prior menu or looking at their website if not updated. As such, the procedures addressed the purpose of triangulation mentioned by Farquhar et al. (2020), namely, convergence, complementarity and divergence among the data.

\section{Data Analysis}

Despite the benefits of utilizing analysis via computer software in qualitative studies being widely known (see, for example, Sinkovics and Alfoldi, 2012), manual coding allowed the researchers to get closer to the data in this study. Specifically, consistent with the terminology of Stake (1995), the researchers manually coded data in respect of key 'issues' under investigation. Furthermore, use of progressive focusing meant the researchers derived themes and sub-themes, and therefore screened-out all others (Sinkovics and Alfoldi, 2012). The researchers employed an adapted version of what is termed the 'Gioia Methodology/Approach' (Gioia et al., 2013), as illustrated in Appendix 2. In doing so, coding was undertaken whereby first order quotes related to second order themes, and subsequently, these led to the aggregated dimension. To allow for contrasting perspectives, the research team was comprised of three members from particular cultural backgrounds. Consequently, this cross-cultural analytical approach is broadly consistent with Jamal and Chapman (2000) that takes an emic and etic perspective. The guidelines of Morrow (2005) referring to the 'trustworthiness' of the data were addressed, namely, credibility, transferability, dependability and confirmability. To illustrate, this study specified a research 'boundary', triangulation occurred; additionally, discussions took place between the researchers to agree the issues of importance arising from the investigation. 


\section{Findings}

\section{Overview}

To avoid this study's findings appearing descriptive in nature, analysis resulted in three key inter-related sub-themes via employing an adapted Gioia approach (as depicted in Appendix 2) that addressed the objective of this study mentioned earlier. Therefore, to minimize repetition and for the purpose of clarity due to the inter-relationships among sub-themes, discussion follows in this section; however, Table 1 offers a summary of key insights. Two overall linking issues associated with inter-firm collaboration were that interviewees (irrespective of their ethnic origin, age or gender) were unanimous about first, the role of changing environmental conditions having an impact on their respective businesses' survival and indeed the uncertainty moving forward. Second, interviewees' decisionmaking was resource-led; for example, where owner-managers were explicitly concerned about finances vis-à-vis operating procedures in meeting customers' needs. They all utilized network ties with counterparts they trusted (especially non-directly competing businesses selling a different cuisine) to gain knowledge in respect of inter-firm collaborative activities. Such an approach was consistent with the notion of developing 'psychological contracts' as opposed to those that were contractually bound. That said, the extent of their readiness for change together with strategic flexibility varied, especially given the perceived costs of pivoting aspects of their business models.

[Insert Table 1 about here]

\section{Network Ties in Inter-firm Collaboration}

All interviewees talked about the importance of weak and strong ties in respect of network partners. However, a key point of variation in the data related to strong ties based on family relationships together with members of co-ethnic communities as opposed to weaker ties outside of family and their co-ethnic communities. Although practitioner discourse varied (avoiding academic terminology), a key consideration related to what was essentially the local hospitality ecosystem in which businesses were located, whereby a geographical area affected networks ties. For example, various interviewees discussed existing ties via a business association that became stronger following 
the COVID-19 outbreak; the benefit being competing restaurants experienced mutually beneficial outcomes. To illustrate, irrespective of the pandemic, a business association helped facilitate customer visits to a cluster; hence, it was a mechanism for members to share knowledge and add value to customers leading to enhanced performance (as per a stakeholder perspective of resource-based theory). Particular interviewees provided specific examples like mentioning that members benefited from issues such as decorative lighting throughout the year, through to features on a seasonal basis like Halloween and Christmas. However, it is re-emphasized that all interviewees mentioned network relationships extending to those businesses in other geographic areas away from where they were located, through family, cultural and other social ties.

\section{Inter-firm Collaboration Reducing Uncertainty}

Returning to the pandemic crisis more specifically, to reduce uncertainty and facilitate learning, all interviewees utilized their network partners' knowledge regarding perceptions towards legislation that could change at any time. This legislation not only affected businesses' performance (including likelihood of survival) within the province as a whole, but those situated in a specific region within a province, due to local spikes in COVID-19 cases. In fact, following closure of in-house dining, considerations extended to different rules being in effect within a neighbouring province affecting first, patio dining and second, in-house dining (subject to social distancing) re-opening quicker, but then subsequently closing at different times as circumstances changed during the pandemic. Consequently, in certain parts of a province, customers might be prepared to drive across the provincial border or to areas further afield in their own providence. This was an issue less likely (at least on a regular basis) prior to the COVID-19 outbreak; hence, affecting the nature of competition and customer behavior vis-à-vis restaurants in this study.

Indeed, learning was important regarding practices that worked or did not work for restaurants in other regions that allowed, for example, either patio or in-house dining earlier than other areas. As such, a consistent message from all interviewees was to utilize whatever network relationships they could to gain information and then to check the accuracy with others in their network. Hence, the COVID-19 pandemic had changed the degree to which sharing 
of information took place (within and across ethnic community members) due to the necessity to learn and act quickly based on evolving circumstances. This was made all the more important, since certain guidelines as opposed to mandatory legal requirements existed at various periods, providing uncertainty over the actions ownermanagers should take to enhance performance; also, over what timescale. Illustrations included the type of masks staff should wear, the need to take customers' temperatures, asking customers to use hand sanitizer, and so on.

\section{Using Inter-firm Collaboration to Pivot Business Models}

It was therefore important that under-resourced owner-managers used the knowledge from inter-firm collaborative activities to pivot their business models where legally allowed to do so (and exploiting loopholes in grey areas like rules associated with patio dining), alongside reacting to perceived customers' expectations. However, the uncertainty of when 'waves' of the pandemic would end (and/or vaccines distributed) together with a potential variant on the initial strain of the virus causing more lockdowns, complicated decision-making. Not least, in respect of the extent to which owner-managers pivoted business models as a survival and/or performance-enhancing strategy. A prime example being that as circumstances evolved, all firms (irrespective of ethnicity) were able to pivot quickly to a take-out option, as soon as legislation prohibited in-house dining. That is not to say all restaurants offered takeouts of the prior full menu, but typically a reduced menu of popular and easy to prepare items to minimize costs and avoid wastage. In fact, certain types of ethnic cuisine did not easily 'travel', meaning it would arrive at customers' homes at an inferior standard compared to coming straight from a kitchen to a table under prior in-house dining. This provided a difficulty for certain restaurants in maintaining a value proposition of perceived quality among customers, in comparison to reducing menu items and/or finding ways via information sharing to quickly get food to customers' houses in a 'quality' condition.

Various restaurants already had an established take-out option before COVID-19 started and respectively used their own staff (especially family and/or co-ethnic staff) or an intermediary firm for deliveries. Others that were previously dine-in only needed information very quickly to pivot, like which intermediary was most reliable and took 
the lowest margins. Alternatively, whether it was preferable to utilize their own staff and over what geographic area deliveries should cover. Information sharing extended to best practices in regards to managing on-line and walk-in orders as such activities involved a different logistical way of working compared to dining on premises, namely, where the front of house staff controlled the flow of food between the kitchen and customers. One interviewee provided the example of making more money via take-outs compared to the start of COVID-19 as the phone would not stop ringing. For this firm, there was a reduction in staff costs with fewer working (reducing to family and coethnic staff), yet many customers were still paying gratuities for sales on-line, shared among retained staff including those in the kitchen. In that specific restaurant, this led to the unintended consequence of those staff members retained making more money than before the pandemic. A further unintended positive consequence of the pandemic for some restaurants was a change in liquor laws regarding sales of alcohol, such as sales previously prohibited except for customers drinking on-premises. In contrast, most restaurants performed far worse compared with sales prior to COVID-19; hence, a move to survival-oriented objectives.

Nevertheless, the rapid move to a take-out option meant the nature of competition changed alongside business models. Specifically, previously full service restaurants were now competing with firms that were still take-out only like a Greek restaurant now selling kebabs/souvlaki/gyros (terms interchangeable) was competing against fast food take-outs of those same items, with similar examples being Italian restaurants now selling take-out pizzas. Although no interviewee used academic discourse such as 'switching costs', essentially each explained in practitioner terminology that for certain basic items such as the previously mentioned pizzas, customers were typically not loyal unlike their full service restaurant prior to COVID-19; in turn, affecting performance expectations focussed on survival. As such, information regarding how to add value to maintain customer loyalty and avoid switching providers was important, whereby, examples follow.

One illustration involved knowledge sharing leading to a noticeable pivot in certain business models like selling the ingredients of the ethnic cuisine and a menu so customers could cook their own meals in an authentic way at home 
to remind them of their favourite restaurant. Indeed, a further illustration of information sharing extended to the important use of social media, in one case to demonstrate making speciality cocktails associated with the restaurant at home. An interviewee, consistent with a number of firms, indicated that social media helped customers to remain engaged and hopefully loyal to the business. In fact, that same interviewee mentioned some customers said they had particular spirits at home and asked for suggestions what cocktails they could make with those ingredients. In certain cases, use of a database helped enable restaurants to keep customers informed about developments via email, hence engaged and hopefully loyal.

Following the change in evolving legislation to allow patio then subsequently in-house dining (at reduced numbers due to social distancing), knowledge sharing was important to help the under-resourced restaurants. However, it is prudent to mention that not all firms were able to pivot rapidly to patio dining with reduced numbers of customers due to the viability of their business model, so remained with a take-out option. An example involved those prior to COVID-19 with buffets associated with their ethnic cuisine, since to use that business model, a need exists for many people to utilize a buffet to remain viable; this was not possible due to the evolving legislation and especially social distancing. One interviewee that previously had a buffet considered a move to family-style dining on a patio, but then perceived this pivot would not work, as it was not cost effective and food would get cold quickly affecting perceptions of quality. Nevertheless, by utilizing knowledge gained from other firms, a pivot subsequently featured a 'pay per menu item' option of those previously on the buffet; that is, until once again, in-house dining was prohibited following evolving legislation. Restaurants pivoting to patio dining sought various knowledge from network partners, such as ways to facilitate expedited planning agreement via government support to grant a patio in those that did not previously have this (or extend the existing patio subject to adequate space around the premises).

\section{Impact of Wider Environmental Issues on Inter-firm Collaboration}

Interestingly, knowledge sharing extended to considerations regarding the changing weather, since over the warmer months, saving money by not having a covered patio was a risk, as customers would get wet during a storm or 
patio dining would close during bad weather. More important, was knowledge sharing regarding getting a reliable and inexpensive contractor that was short in supply to build a quality structure to protect against rain to facilitate continued dining. This extended to considerations regarding issues like installing heaters in anticipation of winter when it would be very cold, namely, to allow all year patio dining. In other words, the investment would hopefully pay for itself unless patio dining was not allowed (via changing legislation) and enable the restaurant to stay in business except in extreme cold. A key issue involved the need to share information on regulations in relation to patio coverings, such as airflow via the enclosed as opposed to exposed areas to avoid fines. Another example featured information sharing regarding the use of screens to separate parties of customers and hence allow more tables closer together to circumvent social distancing regulations. A further illustration with reduced dining due to social distancing involved knowledge sharing regarding the decision whether to allow reservations or walk-in only on a first come first served basis. Interviewees differed on the utility of this with some saying walk-ins were fair, whereas others suggested reservations allowed planning for numbers of staff working; also, helping to engage loyal customers as a priority that owner-managers wanted to welcome back and retain. As one interviewee stated "customers will not forget".

Knowledge sharing included issues around cleanliness like what was legally mandatory rather than guidelines as legislation evolved. A consideration included the use of specific types of masks for staff that was at one stage a guideline before it became mandatory. For example, even if staff did not want to wear this, certain interviewees enforced this for staff as a way to reassure customers. The majority of interviewees considered this important not just to help prevent the spread of COVID-19, but also to protect themselves and their staff. Similar knowledge sharing considerations extended to ways of asking customers to use hand sanitizer without causing offence; also, if the restaurant should have simply on-line menus or hard copies to reflect perceived cleanliness. In fact, if restaurants utilized hard copies of menus, a consideration involved whether these should be disposable to reassure 
customers of cleanliness. One interviewee stated "some restaurants do not want to sanitize the menus so are using on-line menus."

\section{Inter-firm Collaboration and the Impact on Employees}

Although customer perceptions were important as previously mentioned, a key consideration was retaining good staff given that many restaurants had reduced their labor force and in various firms had typically given priority to employing family members (including extended family members); also, in certain cases those with close co-ethnic ties. A number of interviewees mentioned in various discourse that in times of crisis, a business is (as one specifically mentioned) "only as good as its weakest link". As such, employing reliable staff irrespective of their ethnic background in building resilience was important. Outside of family members, competent casual staff employed prior to the pandemic helped maintain government guidelines/regulations and rebuild customer service expectations. One interviewee gave the example learned via knowledge sharing where certain unreliable staff were forgetting to take customers' temperatures despite this posted as an expectation on the restaurant's website to reassure customers of maintaining health standards. This had influenced employment of perceived reliable staff (as previously mentioned, irrespective of ethnic background) with a customer service-oriented approach based in certain cases on reduced shifts. To retain reliable staff, certain businesses used the opportunity of shutdowns (with the exception of take-outs) to give employees other tasks like stocktaking, cleaning, updating IT systems including use of social media, etc.

\section{Other Relevant Issues}

Shutdowns also allowed one business the opportunity to re-model its interior via using contractors found through knowledge sharing, whereby such large-scale construction would be difficult in times of in-house dining. This issue was less applicable to all remaining firms that were struggling to survive and such an investment would be a large risk and/or they simply could not afford it. More important for the remaining firms was knowledge sharing regarding 
construction associated with patios or minor re-modelling like installing screens to separate tables to comply with social distancing rules.

Finally, all interviewees mentioned discourse involving the need for proactive leadership to make tough decisions during times of uncertainty (like those influenced by restricted finances), even though learning from knowledge sharing was beneficial. In fact, knowledge sharing in ways previously outlined reduced perceived risks in ownermanagers' strategies; hence, facilitating flexibility regarding the likelihood of pivoting aspects of their business models. Considerations included mutual benefits for other businesses and not just their own firm's survival. For example, all interviewees mentioned the need for a number of firms to stay in business to maintain an area's reputation. Especially during times when not in shutdown of in-house dining and indeed in anticipation of the pandemic ending, knowledge sharing enabled a cluster of firms to operate to make it appealing for customers to visit an area. That is, if various firms went out of business, it would not provide a positive image for the local area. Information sharing therefore provided benefits for various individual restaurants' performance, employment of family members and typically co-ethnic staff, plus sustainability of other restaurants in the local proximity.

\section{Discussion}

Although decision-makers in respective firms irrespective of their ethnic background have addressed specific crises in a variety of ways, in the context of the current (at the time of writing) COVID-19 pandemic, the worldwide magnitude of the disruption has been dramatic. For example, the waves of shut-downs, partial re-opening, etc., have taken a huge toll on many under-resourced businesses with low or unstable cash-flows across various sectors (Crick and Crick, 2020; Eggers, 2020). However, earlier research suggests that certain issues affect the likelihood of ethnic minority-owned firms' survival and resilience to environmental disruptions like access to capital, levels of education and limited assets (Bruder et al., 2011 Bewaji et al., 2016; Crick et al., 2016). In fact, to date, the survival strategies of firms with ethnic minority ownership at a time of severe market disruption/crisis remains underresearched. The reality is that for a number of trade sectors like restaurants containing many ethnic minority-owned 
firms (Ram et al., 2000a; 2000b; 2002; Jang et al., 2011), as Schwartzel et al. (2020) note: "the new normal will look anything but."

Irrespective of ownership considerations, Rivera (2020) asks an important question: what are the key organizational issues needed to recover from such crises? While there may be many factors affecting an answer to this question, consistent with resource-based theory (Barney, 1991; 2018), decision-makers may possess certain assets, but still need to exhibit readiness for change (Hughes et al., 2020), namely, strategic flexibility (Priem and Butler, 2001). Consequently, it is important that they are able to evolve their business models (Osterwalder and Pigneur, 2010; Gassmann et al., 2014). However, certain owner-managers are under-resourced; hence, a body of literature exists on the notion of inter-firm collaboration as a performance-enhancing strategy (Bengtsson and Kock, 2014; Bouncken and Kraus, 2013; Estrada and Dong, 2020), providing a focus for this current study. Not least, because of the social capital earlier studies have identified among certain ethnic communities, including those that are familyowned (Werbner, 1994; Chaudhry and Crick, 2004; Crick et al., 2016). The notion of symbiotic entrepreneurship occurring across both domestic and international networks has existed for some time (Etemad et al., 2001; Wright and Dana, 2003; Dana et al., 2008), namely, independent firms cooperating voluntarily for performance-enhancing reasons like increased efficiency and profit. Nevertheless, unique insights emerge from this current study in respect of survival strategies of restaurants with ethnic-minority ownership in response to COVID-19. In building on this earlier cross-disciplinary literature, the following contributions arise from this current study with associated implications for practitioners that are outlined in a later section.

Despite under-resourced restaurants with owner-managers of different ethnic minority backgrounds having the option to internalize decision-making and employ an individualistic business model, unique insights featured engaging in knowledge sharing as a performance-enhancing inter-firm collaborative activity in light of evolving environmental uncertainty. There was a need to utilize both weak and strong ties within and across ethnic communities as a survival strategy. These insights demonstrated that inter-firm collaboration provides owner- 
managers with knowledge to help decision-making for mutual benefits (building on resource-based theory as per Barney, 1991; 2018). Furthermore, this study builds on the 'outside-in' approach of Day $(2014 ; 2020)$ whereby the utilization of resources and capabilities should be market-led. In doing so, not only are owner-managers' strategies responsive to market conditions (like the disruption caused by COVID-19 in this current study), but also a recognition exists that instead of 'de-railing' competitors, rivals can collaborate for mutually beneficial performance-enhancing reasons. In this current study, irrespective of the ethnic background of owner-managers, it was perceived as mutually beneficial to share knowledge to keep all firms operating and not least to maintain the reputation of an area. Under such circumstances, this study suggests the potentially 'paradoxical' strategy of cooperating with competitors using the notion of inter-firm collaboration or 'coopetition' (as per the definition of Bengtsson and Kock, 2014) appears in contrast a seemingly 'rational' strategy to cope with environmental uncertainty (Crick and Crick, 2020).

The importance of social capital is noted in earlier studies irrespective of firms' ethnic ownership (building on Visentin et al., 2021). Specifically, this manifested in owner-managers of restaurants building trust via relational network ties consistent with the notion of 'psychological contacts' (Crick and Crick, 2021a) and engaging in interfirm collaborative activities with complementary partners to minimize tensions (Raza-Ullah et al., 2014; Crick, 2020). In turn, this supported a stakeholder perspective of resource-based theory (as per Barney, 2018). This was important since the strength of network ties varied among rivals and owner-managers needed to reach an optimal balance, not engaging in too much or too little inter-firm collaboration (as per Luo et al., 2007). In particular, ownermanagers wanted customers to visit their geographic area so all restaurants of different ethnic cuisines benefited, hence networks existed such as via their local business association. As such, inter-firm collaboration was especially important with complementary partners selling different ethnic cuisines rather than the same cuisine. Due to network ties including those based on the ethnic origins of owner-managers, knowledge sharing also took place across local regions, such as via owners of Italian restaurants who were not direct competitors due to the geographic proximity 
of their respective establishments, but had social capital like through family and community ties. Even so, in further building on the work of Barney (2018), the dynamic circumstances surrounding this current study (the need for survival) raises questions over the likelihood of inter-firm collaboration continuing after the pandemic ends or rather the magnitude of the activities across restaurants with different ethnic ownership. Unfortunately, such questions are impossible to answer in this current study, as they are speculative in nature as the pandemic continues (at the time of writing); hence, offering avenues for future research (see the final section).

Moreover, this study provides new insights highlighting that irrespective of the levels of inter-firm collaboration manifesting in particular information sharing among trustworthy and complementary partners during COVID-19 as a survival strategy, this was not enough. Instead, the changing nature of environmental circumstances emphasized the notion of 'strategic flexibility' (building on Priem and Butler, 2001). In other words, irrespective of the extent to which information sharing occurred based on the strength of relationships, decision-makers' ability to rapidly evolve/pivot aspects of their business models in line with changing circumstances was important alongside associated learning (as per Osterwalder and Pigneur, 2010; Gassmann et al., 2014). These considerations lead to conclusions, implications and areas for further research.

\section{Conclusions, Implications and Future Research}

\section{Conclusions}

The first conclusion is that inter-firm collaboration can provide decision-makers, irrespective of ethnicity, with resources and capabilities (like knowledge in this current study) as a mutually beneficial strategy to help performance related outcomes during a market disruption such as the contemporary COVID-19 pandemic crisis. The second conclusion is that assuming owner-managers engage in inter-firm collaboration, developing trust and engaging in relationships with complementary partners is important to minimize tensions. The third conclusion is that simply having enhanced resources/capabilities may not be enough. Therefore, strategic flexibility is important in respect of decision-makers' business models responding to environmental conditions during a crisis. Specifically, 
a collaborative outside-in (market-led) approach is important in the resources/capabilities-performance relationship. The fourth conclusion arises from the third; that is, irrespective of whether COVID-19 continues for some time after the time of writing or indeed ends following vaccines being distributed, owner-managers need to evaluate the utility of inter-firm collaboration such as with whom this takes place and the extent/magnitude of social capital including co-ethnic and inter-ethnic ties. In other words, decision-makers should in principle try to reach an optimum balance that may be difficult in practice, namely, to ensure mutually beneficial outcomes arise among partners. Such conclusions lead to several implications for practitioners.

\section{Practitioner Implications}

First, although certain market disruptions have a greater impact than other ones as evidenced by previous events (such as financial and health crises), owner-managers need to balance risks/rewards considerations associated with inter-firm collaboration regarding the amount of knowledge sharing that takes place. Indeed, irrespective of the potential merits of such collaboration, there is still a degree of rivalry involved. This leads to the second implication whereby the importance of engaging in relationships with trustworthy and complementary partners cannot be overstated. Utilizing weak and strong network ties is therefore important to determine levels of trust over time, but ownermanagers should not be over reliant on partners in case opportunistic behavior results. For example, it is important to be aware of signs such as one-sided flows of knowledge.

Third, it is important that decision-makers exhibit strategic flexibility to allow them to pursue alternative opportunities in the event they face a market disruption. What this means in practical terms is that owner-managers should be open-minded, proactive and exhibit leadership in ensuring they are able to pivot aspects of their business model in response to market-led circumstances. Indeed, in the case of COVID-19, the future is uncertain at the time of this current study in terms of what will become 'the new normal'. Nevertheless, owner-managers need to be openminded to issues associated with innovative behavior and creative regarding trial and error (subject to funds) to establish what works and does not work; hence, learn and adapt accordingly. While arguably, certain issues are 
predictable like concerns over 'cleanliness' and not spreading COVID-19, other market-led issues are less certain in the 'new normal' regarding customer behavior. However, practices are only as good as their weakest link and so decision-makers need to maintain the employment of good staff; therefore, recruitment, training and retention approaches are important. For example, such activities taking place via staff with good customer service records to maintain positive relationships with patrons may appear obvious. Perhaps less obvious, it is also incumbent on decision makers to be market-led and that may affect employment practices. This may include (but is not limited to), the extent to which they personally or with the employment of competent staff, utilize technology in the 'new normal'. To illustrate, creating a database and using social media to facilitate customer engagement and retention via an on-line presence. In doing so, it is important to keep customers informed of what is happening, maintain relationships, and continue to offer perceived value; otherwise, hospitality-oriented business models (not least among firms with ethnic minority ownership) are likely to be unsustainable.

\section{Limitations and Avenues for Future Research}

Despite this investigation contributing to the existing literature, certain limitations exist offering avenues for future research. First, although data collection took place from various sources (interviewees from ethnic minority backgrounds together with secondary data where possible), the findings nevertheless relied on key informants. Even so, due the nature of the small restaurants with flat hierarchies (often with family employment) and the research issues involved, the value of collecting information from other interviewees was questionable. Second, sector practices across countries are likely to vary and not least due to legislation. Consequently, studies in different institutional contexts are likely to provide further unique insights. Indeed, in the broader hospitality/tourism sector, opportunities exist to extend this study into businesses such as spas and hotels irrespective of ethnic ownership to gain deeper insights. Third, a quantitative research design offers the opportunity for generalizable results where ethnic origin of owners does not necessarily feature (or potentially acts as a control variable). However, the changing 
nature of the issues associated with the COVID-19 pandemic means that unless follow-up research is undertaken, aggregated cross-sectional data will exhibit its own limitations.

Fourth, returning to a point alluded to earlier, a longitudinal research design is therefore preferable and that may employ a mixed methods approach so associated interviews allow depth regarding 'how and why' issues. Understanding how inter-firm collaborative strategies evolve or end (and why) are of particular interest. For example, the stimuli and barriers that affect inter-firm collaboration and the magnitude of activities. In fact, the extent to which inter-firm collaboration extends to community ties is of interest; specifically, whether customers living nearby will continue to support local restaurants and the mechanisms to facilitate this behavior (in addition to engaging customers located further away). Fifth, an opportunity exists to employ different theoretical lenses to offer further insights into owner-managers' behavior following the market disruption. Nevertheless, in closing, these limitations were not significant problems in respect of the research objective under investigation; instead, they highlight opportunities for future research either with an ethnic minority or more generic entrepreneurship focus. 


\section{References}

Abdullah, F., Ingram, A., and Welsh, R. (2009), "Managers' perceptions of tacit knowledge in Edinburgh's Indian restaurants," International Journal of Contemporary Hospitality Management, Vol. 21 No. 1, pp. 118-127.

Aliaga-Isla, R., and Rialp, A. (2013), "Systematic review of immigrant entrepreneurship literature: Previous findings and ways forward," Entrepreneurship and Regional Development, Vol. 25 No. 9-10, pp. 819-844.

Alonso, A.D., Kok, S.K., Bressan, A., O'Shea, M., Sakellarios, N., Solis, M.A.B., and Santoni, L.J. (2020), "COVID19, aftermath, impacts, and hospitality firms: An international perspective," International Journal of Hospitality Management, Vol. 91 No. Oct, pp. 102654.

Arregle, J.L., Hitt, M.A., Sirmon, D.G., and Very, P. (2007), "The development of organizational social capital: Attributes of family firms", Journal of Management Studies, Vol. 44 No. 1, pp. 73-95.

Baden-Fuller, C., and Haefliger, S. (2013), "Business models and technological innovation," Long Range Planning, Vol. 46 No. 6, pp. 419-426.

Barney, J.B. (1991), "Firm resources and sustained competitive advantage," Journal of Management, Vol. 17 No. 1, pp. 99-120.

Barney, J.B. (2018), "Why resource-based theory's model of profit appropriation must incorporate a stakeholder perspective," Strategic Management Journal, Vol. 39 No. 13, pp. 3305-3325.

Basu, A. (2011), From 'break out' to 'breakthrough': Successful market strategies of immigrant entrepreneurs in the UK," International Journal of Entrepreneurship, Vol. 14 No. Jan, pp. 59-81.

Baum, T., and Hai, N.T.T. (2020), "Hospitality, tourism, human rights and the impact of COVID-19," International Journal of Contemporary Hospitality Management, Vol. 32 No. 7, pp. 2397-2407.

Baum, T., Mooney, S.K.K., Robinson, R.N.S., and Solnet, D. (2020), "COVID-19's impact on the hospitality workforce - new crisis or amplification of the norm?" International Journal of Contemporary Hospitality Management, Vol. 32 No. 9, pp. 2813-2829.

BBC News (2020), "Coronavirus panic-buying: No risk to food supplies due to outbreak." Retrieved from: https://www.bbc.co.uk/news/uk-northern-ireland-51957532 [Accessed Various Dates].

Beck, S., and Prügl, R. (2018), "Family firm reputation and humanization: Consumers and the trust advantage of family firms under different conditions of brand familiarity", Family Business Review, Vol. 31 No. 4, pp. 460482.

Bernal, S.M.H., Burr, C., and Johnsen, R.E. (2002), "Competitor networks: International competitiveness through collaboration", International Journal of Entrepreneurial Behavior \& Research, Vol. 8 No. 5, pp. 239-253.

Bengtsson, M., and Kock, S. (2014), "Coopetition - quo vadis? Past accomplishments and future challenges," Industrial Marketing Management, Vol. 43 No. 2, pp. 180-188.

Bewaji, T., Yang, Q., and Han, Y. (2015), "Funding accessibility for minority entrepreneurs: An empirical analysis", Journal of Small Business and Enterprise Development, Vol. 22 No. 4, pp. 716-733. 
Bouncken, R.B., and Kraus, S. (2013), "Innovation in knowledge-intensive industries: The double-edged sword of coopetition," Journal of Business Research, Vol. 66 No. 10, pp. 2060-2070.

Bouncken, R.B., Gast, J., Kraus, S. and Bogers, M. (2015), "Coopetition: A systematic review, synthesis, and future research directions", Review of Managerial Science, Vol. 9 No. 3, pp. 577-601.

Bouncken, R.B., Fredrich, V., Ritala, P., and Kraus, S. (2018), "Coopetition in new product development alliances: Advantages and tensions for incremental and radical innovation," British Journal of Management, Vol. 29 No. 3, Vol. 391-410.

Bouncken, R.B., Fredrich, V., and Kraus, S. (2020), "Configurations of firm-level value capture in coopetition", Long Range Planning, Vol. 53 No. 1, pp. 101869.

Breier, M., Kallmuenzer, A., Clauss, T., Gast, J., Kraus, S., and Tiberius, V. (2021), "The role of business model innovation in the hospitality industry during the COVID-19 crisis," International Journal of Hospitality Management, Vol. 92 No. Jan, pp. 102723.

Brizek, M.G., Frash, R.E., McLeod, B.M., and Patience, M.O. (2021), "Independent restaurant operator perspectives in the wake of the COVID-19 pandemic," International Journal of Hospitality Management, Vol. 93 No. Feb, pp. 102766.

Bruder, J., Neuberger, D., and Räthke-Döppner, S. (2011), "Financial constraints of ethnic entrepreneurship: Evidence from Germany," International Journal of Entrepreneurial Behavior \& Research, Vol. 17 No. 3, pp. 296-313.

Canada.ca (2020), "COVID-19 benefits and services", Retrieved from: https://www.canada.ca/en/services/benefits/covid19-emergency-benefits.html [accessed various dates].

Canziani, B.F., Welsh, D.H.B., Dana, L-P., and Ramadani, V. (2020), "Claiming a family brand identity: The role of website storytelling", Canadian Journal of Administrative Sciences, Vol. 37 No. 1, pp. 68-81.

Carnevale, J.B., and Hatak, E. (2020), "Employee adjustment and well-being in the era of COVID-19: Implications for human resource management," Journal of Business Research, Vol. 116 No. Aug, 183-187.

Carter, S., Mwaura, S., Ram, M., Trehan, K., and Jones, T. (2015), "Barriers to ethnic minority and women's enterprise: Existing evidence, policy tensions and unsettled questions," International Small Business Journal, Vol. 33 No. 1, pp. 49-69.

Chaudhry, S., and Crick, D. (1998), "Export information providers: Are they meeting the needs of SMEs?", Marketing Intelligence \& Planning, Vol. 16 No. 3, pp. 141-149.

Chaudhry, S., and Crick. D. (2003), "Small Asian-owned retail businesses in the UK: An exploratory investigation", Marketing Intelligence \& Planning, Vol. 21 No. 6, pp. 346-356.

Chaudhry, S., and Crick, D. (2004), "The business practices of small Chinese restaurants in the U.K: An exploratory investigation", Journal of Strategic Change, Vol. 13 No. 1, pp. 37-49.

Chen, I.-S. (2020), "Turning home boredom during the outbreak of COVID-19 into thriving at home and career selfmanagement: The role of online leisure crafting", International Journal of Contemporary Hospitality Management, Vol. 32 No. 11, pp. 3645-3663. 
Chiambaretto, P., Bengtsson, M., Fernandez, A-S., and Näsholm, N.H. (2020), "Small and large firms' trade-off between benefits and risks when choosing a coopetitor for innovation", Long Range Planning, Vol. 53 No. 1, pp. 101876.

Chuo, H-Y. (2014), "Restaurant diners' self-protective behavior in response to an epidemic crisis," International Journal of Hospitality Management, Vol. 38 No. Apr, pp. 74-83.

Chowdhury, M., Prayag, G., Patwardhan, V., and Kumar, N. (2020), "The impact of social capital and knowledge sharing intention on restaurants' new product development", International Journal of Contemporary Hospitality Management, Vol. 32 No. 10, pp. 3271-3293.

Chreim, S., Spence, M., Crick, D., and Liao, X. (2018), "Review of female immigrant entrepreneurship research: Past findings, gaps and ways forward", European Management Journal, Vol. 36 No. 2, pp. 210-222.

Chua, J.H., Chrisman, J.J., and Sharma, P. (1999), "Defining the family business by behavior", Entrepreneurship Theory and Practice, Vol. 23 No. 4, pp. 19-39.

CNN (2020), "Detroit mom-and-pop restaurants, forced to close due to Coronavirus, now cook meals for homeless." Retrieved from: https://edition.cnn.com/2020/03/29/us/detroit-coronavirus-chefs-restaurants-homeless-iywtrnd/index.html [30.3.2020].

Crick, D. (1992), "UK export assistance: Are we supporting the best programmes?", Journal of Marketing Management, Vol. 8 No. 1, pp. 81-92.

Crick, D., and Chaudhry, S. (2000), "U.K. SMEs' awareness, use, and perceptions of selected government export assistance: An investigation into the effect of ethnicity", International Journal of Entrepreneurial Behaviour \& Research, 6(2), pp. 72-89.

Crick, D., Chaudhry, S., and Crick, J.M. (2016), "Trading in a competitive environment: South-Asian restaurants in the UK," Strategic Change, Vol. 25 No. 4, pp. 371-382.

Crick, D., Chaudhry, S., and Crick, J.M. (2018), "Risks/rewards and an evolving business model: A case study of a small lifestyle business in the UK tourism sector", Qualitative Market Research: An International Journal, Vol. 21 No. 2, pp. 143-165.

Crick, D. an,d Crick, J.M. (2015), "Learning and decision making in marketing planning: A study of New Zealand vineyards", Marketing Intelligence \& Planning, Vol. 33 No. 5, pp. 707-732.

Crick, J.M. (2015), Bridging the gap between threshold and dynamic capabilities: a qualitative study of the collaboration strategies of New Zealand wineries. Unpublished MBS thesis in Management, Massey University, New Zealand.

Crick, J.M. (2020), "The dark-side of coopetition: When collaborating with competitors is harmful for company performance", Journal of Business \& Industrial Marketing, Vol. 35 No. 2, pp. 318-337.

Crick, J.M. (2021), "Qualitative research in marketing: What can academics do better?", Journal of Strategic Marketing, Earlycite. DOI: 10.1080/0965254X.2020.1743738.

Crick, J.M., and Crick. D. (2016), "Developing entrepreneurial resilience in the UK tourism sector", Strategic Change, Vol. 25 No. 3, pp. 315-325. 
Crick, J.M., and Crick, D. (2018), "Angel investors' predictive and control funding criteria: The importance of evolving business models, Journal of Research in Marketing and Entrepreneurship, Vol. 20 No. 1, pp. 34-56.

Crick, J.M., and Crick, D. (2019), "Developing and validating a multi-dimensional measure of coopetition, Journal of Business and Industrial Marketing, Vol. 34 No. 4, pp. 665-689.

Crick, J.M., and Crick, D. (2020), "Coopetition and COVID-19: Collaborative business-to-business marketing strategies in a pandemic crisis," Industrial Marketing Management, Vol. 88 No. July, pp. 206-213.

Crick, J.M., and Crick, D. (2021a), "The dark-side of coopetition: Influences on the paradoxical forces of cooperativeness and competitiveness across product-market strategies," Journal of Business Research, Vol. 122 No. Jan, pp. 226-240.

Crick, J.M., and Crick, D. (2021b), "Coopetition and sales performance: evidence from non-mainstream sporting clubs", International Journal of Entrepreneurial Behavior \& Research, Vol. 27 No. 1, pp. 123-147.

Crick, J.M., Crick, D., and Chaudhry, S. (2021a), "The dark-side of coopetition: It's not what you say, but the way that you do it", Journal of Strategic Marketing, Earlycite. DOI: 10.1080/0965254X.2019.1642936.

Crick, J.M., Karami, M., and Crick, D. (2021b), "The impact of the interaction between an entrepreneurial marketing orientation and coopetition on business performance", International Journal of Entrepreneurial Behavior \& Research, Earlycite, https://doi.org/10.1108/IJEBR-12-2020-0871.

Cui, V., Yang, H., and Vertinsky, I. (2018), "Attacking your partners: Strategic alliances and competition between partners in product-markets," Strategic Management Journal, Vol. 39 No. 12, pp. 3116-3139.

Czakon, W., and Czernek, K. (2016), "The role of trust-building mechanisms in entering into network coopetition: The case of tourism networks in Poland," Industrial Marketing Management, Vol. 57 No. 1, pp. 64-74.

Czakon, W., Srivastava, M. K., Le Roy, F., and Gnyawali, D.R. (2020), "Coopetition strategies: Critical issues and research directions," Long Range Planning. Vol. 53 No. 1, 101948.

Dana, L-P. (Ed.). (2007), Handbook of Research on Ethnic Minority Entrepreneurship: A Co-Evolutionary View on Resource Management. Edward Elgar, Cheltenham.

Dana, L-P., and Dana, T.E. (2005), "Expanding the scope of methodologies used in entrepreneurship research", International Journal of Entrepreneurship and Small Business, Vol. 2 No. 1, pp. 79-88.

Dana, L-P., and Dumez, H. (2015), "Qualitative research revisited: Epistemology of a comprehensive approach", International Journal of Entrepreneurship and Small Business, Vol. 26 No. 2, pp. 154-170.

Dana, L-P., Etemad, H., and Wright, R.W. (2008), "Toward a paradigm of symbiotic entrepreneurship", International Journal of Entrepreneurship and Small Business, Vol. 5, No. 2, pp. 109-126.

Dana, L-P., Granata, J., Lasch, F., and Carnaby, A. (2013), "The evolution of co-opetition in the Waipara wine cluster of New Zealand," Wine Economics and Policy, Vol. 2 No. 1, pp. 42-49.

Day, G.S. (2014), "An outside-in approach to resource-based theories," Journal of the Academy of Marketing Science, Vol. 42 No. July, pp. 27-28. 
Day, G.S. (2020), "The dynamics of customer value propositions: An outside-in perspective," Industrial Marketing Management, Vol. 87 No. May, pp. 316-319.

Demangeot, C., and Sankaran, K. (2012), "Cultural pluralism: Uncovering consumption patterns in a multicultural environment," Journal of Marketing Management, Vol. 28 No. 7-8, pp. 760-783.

Eggers, F. (2020), "Masters of disasters? Challenges and opportunities for SMEs in times of crisis," Journal of Business Research, Vol. 116 No. Aug, pp. 199-208.

Estrada, I., and Dong, J.Q. (2020), "Learning from experience? Technological investments and the impact of coopetition experience on firm profitability," Long Range Planning, Vol. 53 No. 1, 101866.

Estrada-Robles, M., Williams, N., and Vorley, T. (2020), "Navigating institutional challenges in Mexico: The role of social capital in entrepreneurial families", International Journal of Entrepreneurial Behavior \& Research, Vol. 26 No. 1, pp. 98-121.

Etemad, H., Wright, R.W., and Dana, L-P., (2001), "Symbiotic international business networks: Collaboration between small and large firms", Thunderbird International Business Review, Vol. 43, No. 4, pp. 481-499.

Farquhar, J., Michels, N., and Robson, J. (2020), "Triangulation in industrial qualitative case study research: Widening the scope," Industrial Marketing Management, Vol. 87 No. May, pp. 160-170.

Felzensztein, C., Gimmon, E. and Carter, S. (2010), "Geographical co-location, social networks and inter-firm marketing co-operation: The case of the salmon industry", Long Range Planning, Vol. 43 Nos. 5/6, pp. 675690.

Felzensztein, C., Brodt, S.E., and Gimmon, E. (2014), "Do strategic marketing and social capital really matter in regional clusters? Lessons from an emerging economy of Latin America", Journal of Business Research, Vol. 67 No. 4, pp. $498-507$.

Felzensztein, C., Deans, K.R., and Dana, L-P. (2019), "Small firms in regional clusters: Local networks and internationalization in the Southern Hemisphere," Journal of Small Business Management, Vol. 57 No. 2, pp. 496-516.

Felzensztein, C., and Gimmon, E (2021), "The emergence of family entrepreneurship in the transition economy of Cuba", International Journal of Emerging Markets, Forthcoming.

Financial Times (2020), "Coronavirus." Retrieved from: https://www.ft.com/content/0e7484f5-737f-3eb9-8ec68b32df97d89e [Accessed Various Dates].

Foroudi, P., Jin, Z., Gupta, S., Melewar, T.C., and Foroudi, M.M. (2016), "Influence of innovation capability and customer experience on reputation and loyalty," Journal of Business Research, Vol. 69 No. 11, pp. 48824889.

Foroudi, P., Tabaghdehi, S.A.H., and Marvi, R. (2021), "The gloom of the COVID-19 shock in the hospitality industry: A study of consumer risk perception and adaptive belief in the dark cloud of a pandemic," International Journal of Hospitality Management, Vol. 92 No. Jan, pp. 102717. 
Fortune (2020), "How Global 500 companies are utilizing their resources and expertise during the Coronavirus pandemic." Retrieved from: https://fortune.com/2020/04/13/global-500-companies-coronavirus-responsecovid-19-pandemic/ [12.5.2020].

Fox News (2020), "Coronavirus impact on federal government: closures, travel restrictions and more." Retrieved from: $\quad$ https://www.foxnews.com/politics/coronavirus-impact-on-federal-government-closures-travelrestrictions-and-more [Accessed Various Dates].

Gassmann, O., Frankenberger, K., and Csik, M. (2014), The Business Model Navigator. FT Publishing, Harlow.

Gao, H., Xie, J., Wang, Q., and Wilbur, K. C. (2015), "Should ad spending increase or decrease before a recall announcement? The marketing-finance interface in product-harm crisis management," Journal of Marketing, Vol. 79 No. 5, pp. 80-99.

Geldes, C., Felzensztein, C., Turkina, E., and Durand, A. (2015), "How does proximity affect inter-firm marketing cooperation? A study of an agribusiness cluster", Journal of Business Research, Vol. 68 No. 2, pp. 263-272.

Gioia, D.A., Corley, K.G., and Hamilton, A.L. (2013), "Seeking qualitative rigor in inductive research: Notes on the Gioia methodology," Organizational Research Methods, Vol. 16 No. 1, pp. 15-31.

Globalnews.ca (2020a), "800,000 restaurant jobs lost in Canada in March amid COVID-19: Survey." https://globalnews.ca/news/6767041/coronavirus-restaurants-canada/ [accessed various dates].

Globalnews.ca (2020b), "Restaurants are set to reopen, but your meal will come with a side of COVID-19 rules." https://globalnews.ca/news/7070381/coronavirus-canada-restaurants-reopening-plan/ [accessed various dates].

Gnyawali, D.R., and Charleton, T.R. (2018), "Nuances in the interplay of competition and cooperation: Towards a theory of coopetition," Journal of Management, Vol. 44 No. 7, pp. 2511-2534.

Granata, J., Lasch, F., Le Roy, F., and Dana, L-P. (2018), "How do micro-firms manage coopetition? A study of the wine sector in France," International Small Business Journal, Vol. 36 No. 3, pp. 331-355.

Guttentag, D.A., and Smith, S.L.J. (2017), "Assessing Airbnb as a disruptive innovation relative to hotels: Substitution and comparative performance expectations," International Journal of Hospitality Management, Vol. 64 No. Jul, pp. 1-10.

Habbershon, T., and Williams, M. (1999), "A resource-based framework for assessing the strategic advantages of family firms", Family Business Review, Vol. 12 No. 1, pp. 1-25.

Hannah, D.P., and Eisenhardt, K.M. (2018), "How firms navigate cooperation and competition in nascent ecosystems," Strategic Management Journal, Vol. 39 No. 12, pp. 3163-3192.

Herrero, I., and Hughes, M. (2019), "When family social capital is too much of a good thing", Journal of Family Business Strategy, Vol. 10 No. 3, pp. 100271.

Hoffmann, W., Lavie, D., Reuer, J.J., and Shiplov, A. (2018), "The interplay of competition and cooperation," Strategic Management Journal, Vol. 39 No. 12, pp. 3033-3052. 
Hughes, P., Morgan, R.E., Hodgkinson, I.R., Kouropalatis, Y., and Lindgreen, A. (2020), "A diagnostic tool to determine a strategic improvisation readiness index score (IRIS) to survive, adapt, and thrive in a crisis," Industrial Marketing Management, Vol. 88 No. July, pp. 495-499.

Huybrechts, J., Voordeckers, W., Lybaert, N., and Vandemaele S. (2011), "The distinctiveness of family-firm intangibles: A review and suggestions for future research", Journal of Management \& Organization, Vol. 17 No. 2, pp. 268-287.

Independent (2020), "Coronavirus: Supermarkets can now share staff, depots and data to help feed the nation." Retrieved from: https://www.independent.co.uk/news/business/news/coronavirus-supermarkets-uk-staffdepots-food-a9413146.html [29.3.2020].

Israeli, A.A. (2007), "Crisis-management practices in the restaurant industry," International Journal of Hospitality Management, Vol. 26 No. 4, pp. 807-823.

Jamal, A., and Chapman, M. (2000), "Acculturation and inter-ethnic consumer perceptions: Can you feel what we feel," Journal of Marketing Management, Vol. 16 No. 4, pp. 365-391.

Jang, S., Liu, Y., and Namkung, Y. (2011), "Effects of authentic atmospherics in ethnic restaurants: Investigating Chinese restaurants," International Journal of Contemporary Hospitality Management, Vol. 23 No. 5, pp. 662680.

Jiang, Y., and Wen, J. (2020), "Effects of COVID-19 on hotel marketing and management: A perspective article," International Journal of Contemporary Hospitality Management, Vol. 32 No. 8, pp. 2563-2573.

Johnstone, S., Saridakis, G., and Wilkinson, A. (2019), "The global financial crisis, Work and employment: Ten years on", Economic and Industrial Democracy, Vol. 40 No. 3, pp. 455-468.

Jones, T., McEvoy, D., and Barratt, J. (1992), Raising capital for the ethnic minority small business. In Hughes, A. and Storey, D. (Eds.). Financing the Small Firm, Routledge, London.

Jones, T., McEvoy, D., and Barratt, J. (1993), Labour intensive practices in the ethnic minority firm. In Atkinson, J. and Storey, D. (Eds.). Employment, the Small Firm and the Labour Market, Routledge, London.

Jones, T., Ram, M., Edwards, P., Kiselinchev A., and Muchenje, L. (2014), "Mixed embeddedness and new migrant enterprise in the UK," Entrepreneurship \& Regional Development, Vol. 26 No. 5-6, pp. 500-520.

Josiam, B.B., and Monteiro, P.A. (2004), "Tandoori tastes: Perceptions of Indian restaurants in America," International Journal of Contemporary Hospitality Management, Vol. 16 No. 1, pp. 18-26.

Kellermanns, F., Walter, J., Crook, T.R., Kemmerer, B. and Narayanan, V. (2016), "The resource-based view in entrepreneurship: A content-analytical comparison of researchers' and entrepreneurs' views", Journal of Small Business Management, Vol. 54 No. 1, pp. 26-48.

King, C.A. (1995), "What is hospitality?" International Journal of Hospitality Management, Vol. 14 No. 3-4, pp. 219234.

Kloosterman, R.C. (2010), Matching opportunities with resources: A framework for analysing (migrant) entrepreneurship from a mixed embeddedness perspective," Entrepreneurship and Regional Development, Vol. 22 No. 1, pp. 25-45. 
Knight, D.W., Xiong, L., Lan, W., and Gong, J. (2020), "Impact of COVID-19: Research note on tourism and hospitality sectors in the epicenter of Wuhan and Hubei Province, China," International Journal of Contemporary Hospitality Management, Vol. 13 No. 12, pp. 3705-3719.

Kraus, S., Klimas, P., Gast, J., and Stephan, T. (2019), "Sleeping with competitors: forms, antecedents and outcomes of coopetition of small and medium-sized craft beer breweries", International Journal of Entrepreneurial Behavior \& Research, Vol. 25 No. 1, pp. 50-66.

Lascaux, A. (2020), "Coopetition and trust: What we know, where to go next," Industrial Marketing Management, Vol. 84 No. 1, pp. 2-18.

Lavie, D. (2006), "The competitive advantage of inter-connected firms: An extension of the resource-based view", Academy of Management Review, Vol. 31 No. 3, pp. 638-658.

Light, I. (1972), Ethnic Enterprise in America: Business and Welfare Among Chinese, Japanese and Blacks. University of California Press, Berkeley, California.

Lund Pedersen, C., and Ritter, T. (2020), "Preparing your business for a post-pandemic world," Harvard Business Review, Digital Articles.

Luo, X., Rindfleisch, A., and Tse, D.K. (2007), "Working with rivals: The impact of competitor alliances on financial performance," Journal of Marketing Research, Vol. 44 No. 1, pp. 73-83.

Min, P.G. (1987), "Factors contributing to ethnic business: A comprehensive synthesis," International Journal of Comparative Sociology, Vol. 28 No. 3/4, pp. 173-193.

Morrish, S.C., and Jones, R. (2020), "Post-disaster business recovery: An entrepreneurial marketing perspective," Journal of Business Research, Vol. 113 No. May, pp. 83-92.

Morrow, S.L. (2005), "Quality and trustworthiness in qualitative research in counseling psychology," Journal of Counseling Psychology, Vol. 52 No. 2, pp. 250-260.

MSN (2020a), "Industries performing best and worse during the Coronavirus and how they're responding." Retrieved from: https://www.msn.com/en-us/money/markets/industries-performing-best-and-worst-duringthe-coronavirus-—-and-how-theyre-responding/ss-BB12CWOe?ocid=spartanntp (2020) [20.4.2020].

MSN (2020b), "50 popular restaurants that won't reopen after the pandemic." https://www.msn.com/enus/foodanddrink/restaurantsandnews/50-popular-restaurants-that-wont-reopen-after-the-pandemic/ssBB14h1aU?ocid=spartanntp\#image=50 [accessed various dates].

New York Times (2020), "Search for Coronavirus vaccine becomes a global competition." Retrieved from: https://www.nytimes.com/2020/03/19/us/politics/coronavirus-vaccine-competition.html [29.3.2020].

Niemelä T. (2004), "Interfirm cooperation capability in the context of networking family firms: The role of power", Family Business Review, Vol. 17 No. 4, pp. 319-330.

Oc, T., and Tiesdell, S. (1999), "Supporting ethnic minority business: A review of business support for ethnic minorities in city challenge areas." Urban Studies, Vol. 36 No. 10, pp. 1723-1746.

Osterwalder, A., and Pigneur, Y. (2010), Business Model Generation. Wiley, New Jersey. 
Pangarkar, N. (2007), "Survival during a crisis: Alliances by Singapore firms," British Journal of Management, Vol. 18 No. 3, pp. 209-223.

Pantano, E., Pizzi, G., Scarpi, D., and Dennis, C. (2020), "Competing during a pandemic? Retailers' ups and downs during the COVID-19 outbreak," Journal of Business Research, Vol. 116 No. Aug, pp. 209-213.

Papaioannou, G., Mohammed, A-M., Despoudi, S., Saridakis, G., and Papadopoulos, T. (2020), "The role of adverse economic environment and human capital on collaboration within agri-food supply chains", International Journal of Information Management, Vol. 52 No. June, pp 102077.

Parsa, H.G., Self, J.T., Njite, D., and King, T. (2005), "Why restaurants fail," Cornell Hotel and Restaurant Administration Quarterly, Vol. 46 No. 3, pp. 304-322.

Pizam, A. (2009), "The global financial crisis and its impact on the hospitality industry," International Journal of Hospitality Management, Vol. 28 No. 3, pp. 301.

Poblete, C. (2018), "Shaping the castle according to the rocks in the path? Perceived discrimination, social differences, and subjective wellbeing as determinants of firm type among immigrant entrepreneurs," Journal of International Entrepreneurship, Vol. 16 No. 2, pp. 276-300.

Priem, R.L., and Butler, J.E. (2001), "Is the resource-based view a useful perspective for strategic management research?" Academy of Management Review, Vol. 26 No. 1, pp. 57-66.

Ram, M., and Hillin, G. (1994), "Achieving 'break-out': Developing mainstream ethnic minority businesses," Journal of Small Business and Enterprise Development, Vol. 1 No. 2, pp. 15-21.

Ram, M., and Smallbone, D. (2003), "Policies to support ethnic minority enterprise: The English experience," Entrepreneurship and Regional Development, Vol. 15 No. 2, pp. 151-166.

Ram, M., Abbas, T., Sanghera, B., and Hillin, G. (2000a), "Currying favour with the locals': Balti owners and business enclaves," International Journal of Entrepreneurial Behavior \& Research, Vol. 6 No. 1, pp. 41-55.

Ram, M., Sanghera, B., Abbas, T., Barlow, G., and Jones, T. (2000b), "Ethnic minority business in comparative perspective: The case of the independent restaurant sector," Journal of Ethnic and Migration Studies, Vol. 26 No. 3, pp. 495-510.

Ram, M., Jones, T., Abbas, T., and Sanghera, B. (2002), "Ethnic minority enterprise in its urban context: South Asian restaurants in Birmingham," International Journal of Urban and Regional Research, Vol. 26 No. 1, pp. 24-40.

Ratten, V. (2020), "Coronavirus and international business: An entrepreneurial ecosystem perspective," Thunderbird International Business Review, Vol. 62 No. 5, pp. 629-634.

Raza-Ullah, T., Bengtsson, M., and Kock, S. (2014), "The coopetition paradox and tension in coopetition at multiplelevels," Industrial Marketing Management, Vol. 43 No. 2, pp. 189-198.

Reay, T., Jaskiewicz, P., and Hinings, C.R. (2015), "How family, business, and community logics shape family firm behaviour and "rules of the game" in an organizational field", Family Business Review, Vol. 28 No. 4, pp. 292-311. 
Restaurants Canada (2020), "Restaurants Canada COVID-19 Reopening Best Practices." http://www.restaurantscanada.org/wpcontent/uploads/2020/05/RC_COVID19_Reopening_BestPractices.pdf. [accessed various dates].

Ritala, P. (2012), "Coopetition strategy - when is it successful? Empirical evidence on innovation and market performance," British Journal of Management, Vol. 23 No. 3, pp. 307-324.

Ritter, T., and Lund Pedersen, C. (2020), "Assessing Coronavirus' impact on your business model," Harvard Business Review. Digital Articles.

Rivera, M.A. (2019), "The impetus behind interorganizational collaboration: What is its new value proposition for small operators?" International Journal of Hospitality Management, Vol. 83 No. Oct, pp. A1-A2.

Rivera, M.A. (2020), "Hitting the reset button for hospitality research in times of crisis: Covid-19 and beyond," International Journal of Hospitality Management, Vol. 87 No. May, 102528.

Roessl, D. (2005), "Family businesses and interfirm cooperation", Family Business Review, Vol. 18 No. 3, pp. 203214.

Schwartzel, E., Sider, A., and Haddon, H. (2020), "The coronavirus economic reopening will be fragile, partial and slow," Wall Street Journal 13 Apr. www.wsj.com/articles/the-coronavirus-economic-reopening-will-be-fragilepartial-and-slow-11586800447

Security (2020), "Cybersecurity experts come together to fight Coronavirus-related cyberattacks." Retrieved from: https://www.securitymagazine.com/articles/92004-cybersecurity-experts-come-together-to-fightcoronavirus-related-cyberatacks [29.3.2020].

Sheth, J. (2020), "Impact of Covid-19 on consumer behavior: Will the old habits return or die?" Journal of Business Research, Vol. 117 No. Sep, pp. 280-283.

Seo, S., and Jang, S. (2013), "The roles of brand equity and branding strategy: A study of restaurant food crises," International Journal of Hospitality Management, Vol. 34 No. Sep, pp. 192-201.

Sigala, M. (2020), "Tourism and COVID-19: Impacts and implications for advancing and resetting industry and research," Journal of Business Research, Vol. 11 No. Sept, pp. 312-321.

Sinkovics, R.R., and Alfoldi, E.A. (2012), "Progressive focusing and trustworthiness in qualitative research: The enabling role of computer-assisted qualitative data analysis software (CAQDAS)," Management International Review, Vol. 52 No. 6, pp. 817-845.

Sirmon, D.G., and Hitt, M.A. (2003), "Managing resources: Linking unique resources, management, and wealth creation in family firms", Entrepreneurship Theory and Practice, Vol. 27 No. 4, pp. 339-358.

Smallbone, D., Bertotti, M., and Ekanem, I. (2005), "Diversification in ethnic minority business: The case of Asians in London's creative industries," Journal of Small Business and Enterprise Development, Vol. 12 No. 1, pp. 41-56.

Song, H.J., Yeon, J., and Lee, S. (2021), "Impact of the COVID-19 pandemic: Evidence from the U.S. restaurant industry," International Journal of Hospitality Management, Vol. 92 No. Jan, pp. 102702. 
Stafford, G., Yu, L., and Armoo, A.K. (2002), "Crisis management and recovery," Cornell Hotel and Restaurant Administration Quarterly, Vol. 43 No. 5, pp. 27-40.

Stake, R.E. (1995), The Art of Case Study Research, Sage, Thousand Oaks, CA.

Telegraph (2020), "Coronavirus world map: Live tracker of reported COVID-19 cases and deaths. How has the coronavirus outbreak evolved since the disease emerged?" Retrieved from: https://www.telegraph.co.uk/global-health/science-and-disease/live-cases-numbers-coronavirus-world-mapcovid-19/ [1.4.2020].

The Guardian (2020), "Apple and Google team up in bid to use smartphones to track Coronavirus spread." Retrieved from: $\quad$ https://www.theguardian.com/world/2020/apr/10/apple-google-coronavirus-us-app-privacy [11.4.2020].

Tse, A.C.B, So, S., and Sin, L. (2006), "Crisis management and recovery: How restaurants in Hong Kong responded to SARS," International Journal of Hospitality Management, Vol. 25 No. 1, pp. 3-11.

United Kingdom Government (2020), "Staying at home and away from others (social distancing)." Retrieved from: https://www.gov.uk/government/publications/full-guidance-on-staying-at-home-and-away-from-others [29.3.2020].

Velu, C. (2016), "Evolutionary or revolutionary business model innovation through coopetition? The role of dominance in network markets," Industrial Marketing Management, Vol. 53 No. 1, pp. 124-135.

Visentin, M., Reis, R.S., Cappiello, G., and Casoli, D. (2021), "Sensing the virus. How social capital enhances hoteliers' ability to cope with COVID-19," International Journal of Hospitality Management, Vol. 94 No. Apl, pp. 102820.

Wang, Y., and Krakover, S. (2008), "Destination marketing: Competition, cooperation or coopetition?" International Journal of Contemporary Hospitality Management, Vol. 20 No. 2, pp. 126-141.

Washington Post (2020), "U.S. becomes first country to report 100,000 confirmed Coronavirus cases; Trump Defence Production Act." Retrieved from: https://eu.usatoday.com/story/news/nation/2020/03/27/scientiststrack-coronavirus-strains-mutation/5080571002/ [28.3.2020].

Werbner, P. (1994), Renewing an industrial past: British Pakistani entrepreneurship in Manchester. In Brown, J.M. and Foot, R. (Eds.). Migration: The Asian Experience, Palgrave, London, pp. 104-130.

Werbner, P. (2001), "Metaphors of spatiality and networks in the plural city: A critique of the ethnic enclave economy debate," Sociology, Vol. 35 No. 3, pp. 671-693.

Wilson, K.L. and Portes, A. (1980), "Immigrant enclaves: An analysis of the labor market experiences of Cubans in Miami," American Journal of Sociology, Vol. 86 No. 2, pp. 295-319.

Worldometer (2021), "COVID-19 Coronavirus pandemic." Retrieved from: https://www.worldometers.info/coronavirus/ [Accessed Various Dates].

Wright, R.W., and Dana, L-P. (2003), "Changing paradigms of international entrepreneurship strategy", Journal of International Entrepreneurship, Vol. 1 No. pp. 135-152. 
Wyllie, J. (2020), "Coronavirus: North-east charities unite for Feed the City campaign to help those affected by outbreak." Retrieved from: https://www.pressandjournal.co.uk/fp/news/aberdeen/2088556/coronavirusnorth-east-charities-unite-for-feed-the-city-campaign-to-help-those-affected-by-outbreak/ [28.3.2020].

Yan, Y., Dong, J.Q., and Faems, D. (2020), "Not every coopetitor is the same: The impact of technological, market and geographical overlap with coopetitors on firms' breakthrough inventions," Long Range Planning, Vol. 53 No. 1, pp. 101873.

Yang, Y., Liu, H., and Chen, X. (2020), "COVID-19 and restaurant demand: Early effects of the pandemic and stayat-home orders," International Journal of Contemporary Hospitality Management, Vol. 13 No. 12, pp. 38093834.

Zellweger, T.M., Kellermanns, F.W., Eddleston, K.A., and Memili, E. (2012), "Building a family firm image: How family firms capitalize on their family ties", Journal of Family Business Strategy, Vol. 3 No. 4, pp. 239-250. 


\section{Appendix 1: Interview Schedule}

\begin{tabular}{|c|c|}
\hline Research Issues & Sub-Issues \\
\hline $\begin{array}{l}\text { Owner-manager's background and } \\
\text { company data (e.g. Chua et al., } \\
\text { 1999; Crick et al., 2016) }\end{array}$ & $\begin{array}{ll}\text { - } & \text { Interviewee (ethnicity, education, experience) } \\
\text { - } & \text { Year founded } \\
\text { - } & \text { Employees } \\
\text { - } & \text { Key stakeholders business criteria }\end{array}$ \\
\hline $\begin{array}{l}\text { Inter-firm collaboration (e.g. } \\
\text { Geldes et al., 2015; Crick and } \\
\text { Crick, 2020) }\end{array}$ & $\begin{array}{l}\text { Reasons - explore decisions against objectives } \\
\text { Explore what took place, with whom, how and why } \\
\text { - } \\
\text { - } \\
\text { Proximity issues if not covered } \\
\text { What was the impact of COVID-19 }\end{array}$ \\
\hline $\begin{array}{l}\text { Influence on business model (e.g. } \\
\text { Osterwalder and Pigneur, 2010; } \\
\text { Gassmann et al., 2014) }\end{array}$ & $\begin{array}{l}\text { Pre COVID-19 objectives - link to business model } \\
\text { - } \quad \text { Post COVID-19 objectives - link to business model } \\
\text { - } \quad \text { Role/impact of stakeholders including staff/community } \\
\text { - } \quad \text { Performance outcomes (and link to objectives) }\end{array}$ \\
\hline
\end{tabular}


Table 1: Key Findings

\begin{tabular}{|c|c|c|}
\hline Environmental Conditions & Inter-firm Collaboration as a Survival Strategy & Strategic Flexibility \\
\hline Changing legislation & Sharing knowledge over what is legally allowed & $\begin{array}{l}\text { Can decision-makers rapidly adapt to changes in legislation } \\
\text { and pivot their business models? }\end{array}$ \\
\hline Seasonal factors & $\begin{array}{l}\text { Sharing knowledge over good and bad practices of } \\
\text { other firms, especially regarding the weather }\end{array}$ & As above \\
\hline Customers' perceptions & $\begin{array}{l}\text { Sharing knowledge of customer-oriented good and bad } \\
\text { practices regarding other firms }\end{array}$ & $\begin{array}{l}\text { Can decision-makers rapidly adapt business models to } \\
\text { address customers' perceptions/expectations, maintain } \\
\text { loyalty, and keep them engaged? For example, via social } \\
\text { media, changing menus, logistics, and community } \\
\text { initiatives. }\end{array}$ \\
\hline $\begin{array}{l}\text { Labour market and employee } \\
\text { considerations }\end{array}$ & $\begin{array}{l}\text { Sharing knowledge regarding how to retain/retrain good } \\
\text { staff and keep them safe }\end{array}$ & $\begin{array}{l}\text { What can decision-makers do to protect, retain and retrain } \\
\text { good staff as key resources when business models pivot? }\end{array}$ \\
\hline
\end{tabular}




\section{Appendix 2: Data Structure Using an Adapted Gioia (2013) Methodology}

\section{Examples of First-Order Themes}

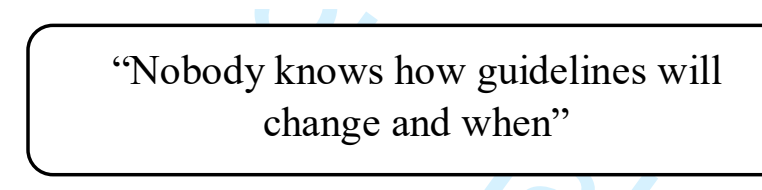

"We are closely watching what is going on in other provinces"

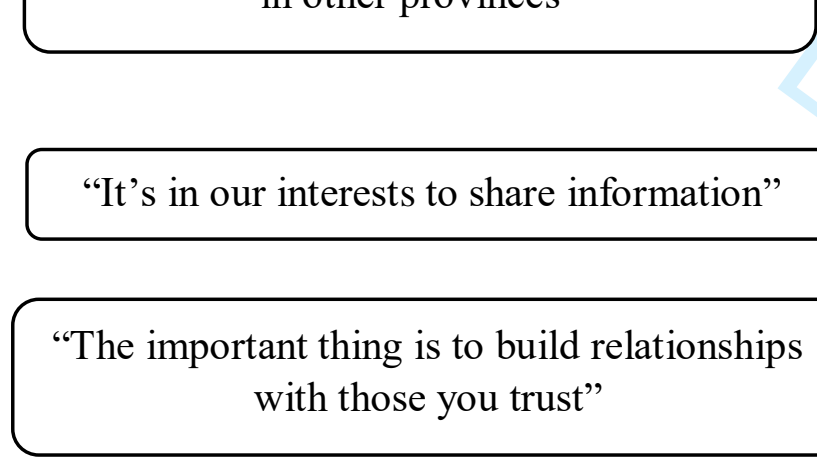

\section{"We all have to be responsive to when guidelines change and move quickly"}

"It's important to keep relationships with customers and find new ways of doing things until we go back to something like before"

\section{Second-Order Themes}
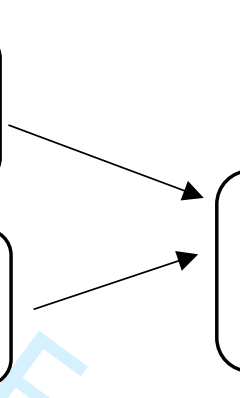

Environmental

considerations
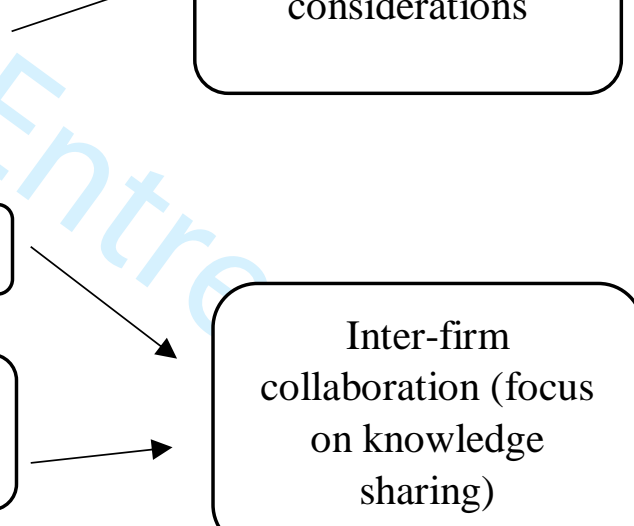

Inter-firm collaboration (focus on knowledge sharing)

Strategic flexibility

\section{Aggregate Dimension}

